\title{
Lineage in Rural China: Social Network or Patriarchal Clan System? Evidence from Its Impact on Irrigation Infrastructure Management
}

\author{
Yu YANG
}

\begin{abstract}
Despite the rapid modernization of the Chinese countryside, informal institutions have remained influential for villagers' lives. While lineage is known as an important informal institution, its influence on rural socio-economic wellbeing is under-researched. Two conceptualizations exist to study lineage; lineage is used as a social network, which is used as a hierarchical organization or patriarchal clan system. This article compares these two conceptualizations in the analysis of a lineage's influence on villagers' contribution to irrigation infrastructure management. In times where formal institutions in rural China have weakened, this article questions how much lineage has taken over some of the functions of formal institutions, such as infrastructure management. Based on a survey in Sichuan Province, the results show that lineage takes effect as both an organization and a social network.
\end{abstract}

Keywords: China; collective action; farmers; lineage; social network

\section{INTRODUCTION}

With rapid economic change, rural China has become a "traditional modern society" [1]. Despite rapid modernization, households' decision-making is still affected by traditional culture and informal institutions. Instances of modernization are, for example, the quick urbanization in China and the related out-migration of farmers and their families, which reached 286.52 million people by 2017. In addition, the industrialization of villages and the related marketization, as well as social polarization, are indications of the modernization of the Chinese countryside. However, the influence of informal institutions has remained somewhat strong [2]. So far, literature on rural China has paid attention to the influence of informal institutions of relationship networks, such as guanxi, trust [3], or mianzi, "losing face", on household decision-making. Lineage culture and its influence on households' decision-making have not yet received enough attention. In times where formal institutions in rural China have weakened, lineage can somewhat take over some of the functions of formal institutions, as it contributes to cooperative behavior and local collective action [3]. This paper makes the case that for the collective task of irrigation in particular, in circumstances of weak formal institutions, informal institutions can have a positive effect on the provision of rural irrigation infrastructures $[3,4]$.

Lineage is considered one of the most important informal institutions in rural China [5-7]. How to analyze lineage is by no means evident, as it comprises both horizontal and vertical structures. Therefore, two different conceptualizations have been used to study lineage. Some studies understand lineage as a kind of social network [8], and other studies conceive it as an organization [5]. Social networks can be rather open structures, where hierarchies are less distinct and can be bridged by network ties. They can thus be very efficient structures to facilitate collective action. Lineage as an organization, foremost, can be understood as being more hierarchical and closed. For lineage as an organization to bring about collective action, "organizational identity" can be considered important. "Organizational identity" is a kind of social identity, which forms through kinship and makes members identify with their lineage group, leading to strong cohesion. Social identity can also facilitate collective action [9]. So far, the implications of these different conceptualizations of lineage have not been examined. If future research is to examine the effect of lineage on collective action in rural China, it is important to know which conceptualization would be appropriate to use. Alternatively, formulated differently, what exactly within lineage triggers farmers' willingness to contribute to collective action-lineage as a social network or lineage as an organization? The aim of this paper is to address this knowledge gap using concepts of irrigation infrastructure management in rural China.

In this study, this article considered irrigation infrastructures. Chinese local governments and village collective organizations are responsible for public tasks like water management. The main financial source for rural public services came from agricultural taxes and fees, before the "agricultural tax abolition" policy in 2006 cut off these sources. The policy significantly increased farmers' income from agricultural operations [10], but it also weakened local governments when pursuing their public tasks, such as providing and managing irrigation infrastructures. "The provision and management of physical infrastructures necessary to utilize the resource (water) is a collective action problem in irrigation systems governance" [11]. Small irrigation infrastructures require collective management as they include e.g. canals, gate valves, air valves, pumps, motors, wells and electronic control equipment, which are jointly used by farmers. Small irrigation infrastructures were often not well managed after 2006, and especially small reservoirs, canals and pump stations were seriously damaged in rural China, which is why the effect of lineage on collective management is empirically interesting and relevant.

In the following, we provide a theoretical framework and research hypotheses with regard to how lineage as social network and lineage as an organization need to be conceived for their empirical analysis. The third section introduces methodology and data analysis. The fourth section provides regression results. In the fifth section, we discuss the effects of lineage networks and lineage organization for the case of small-scale irrigation infrastructures. The final section provides a conclusion 
with recommendations for further research on lineage and collective action in rural China.

\section{THEORETICAL FRAMEWORK AND RESEARCH HYPOTHESES \\ 2.1 Definition of Lineage}

Reforms in the modern history of China have often considered lineage to be part of a backward culture. During the Cultural Revolution, important artefacts of lineage like lineage of a clan's ancestral hall and genealogy were destroyed. Nevertheless, lineage has remained an important informal institution until today.

Lineage members are born into their lineage that can be distinguished based on surnames. Traditionally, lineage members have strong lineage identity, the social and geographic structure of rural China can be summarized as "a pattern of difference sequence" [15], which means that relationships in the countryside were determined by clan members' status within lineage kinship.

In the following, we introduce to how lineage has been conceived differently as an organization and as a social network, and derive hypotheses for our empirical research.

\subsection{Lineage as Social Network and Its Role for Collective Action}

The literature in recent years has defined lineage as a social network [6]; "Lineage networks are a distinctive and prominent feature of Chinese village life", where ancestry is the basis of the relationships between lineage members.

Lineage networks are a kind of social network. The literature on social networks focuses on the analysis of the relationships between individuals, structures, and the influenced individuals' behavior [12]. Collaboration is more likely to occur in well-connected networks, or, stated differently, the strength of ties in social networks is important for collective action. Social networks with strong ties decrease the risks and costs of working together, which can facilitate collective action.

From the above, this article derived the following hypotheses:

Hypothesis 1: The strength of lineage network ties has a positive effect on households' participation in the collective action of irrigation infrastructure management.

Hypothesis 2: The strength of lineage network ties has a positive effect on households' willingness to participate in the collective action of irrigation infrastructure management.

This article makes a distinction between two dependent variables, namely, households' willingness to participate and households' participation. The reason for this is that willingness may be an indicator that respondents think they would have to answer because they are members of a lineage network (i.e., the variable could instead indicate a socially desired response). How much the strength of lineage networks leads to actual behavior will then be measured by hypothesis 1 .

\subsection{Lineage as an Organization}

Lineage as an organization can be thought of as a pyramid structure, where the lineage leader is at the top, followed by the sub-leaders. Patriarchal clan systems have many more criteria to differentiate hierarchies within the clan. Seniority and age play an important role, where seniority relates to the number of generations in a clan. If two lineage leaders are of the same age, the lineage of the older clan has a higher status. For the research at hand, this article will not go further into depth about these norms, but this article will maintain the conclusion that they show lineage as a somewhat hierarchical system, where lineage leaders are responsible to call upon members for activities that are important to the clan. To measure lineage as an organization, "organizational identity" was used as an indicator. Organizational identity is a particular form of social identity [13]. Social identity enhances the probability of collective action [14] by means of cognitive mechanisms [15]. In addition, within organizations, social identity encourages members to participate in collective action [16]. Identity within an organization is said to enhance support and commitment to the organization [17]. A high organizational identity can facilitate individuals in contributing to collective goals $[18,19]$. Organizational identity hence refers to what members perceive, feel, and think about their organization, which is assumed to be a collective, commonly-shared understanding of the organization's distinctive values and characteristics [15]. This article argues that lineage members have feelings of, for example, belongingness and identification with their lineage organization or clan, and that if research wants to understand lineage as an organization, "organizational identity" can help us to find out how far identification with the clan can enhance willingness to participate in collective action, or de facto collective action.

From the above, this article derives the following hypotheses:

Hypothesis 3: Lineage organizational identity has a positive effect on households' participation in the collective action of irrigation infrastructure management.

Hypothesis 4: Lineage organizational identity has a positive effect on households' willingness to participate in the collective action of irrigation infrastructure management.

\section{METHODOLOGY}

\subsection{Data Sources and Description 3.1.1 Data Sources}

The dataset is from a survey that was organized by the last author in Jintang County in the city of Chengdu, Sichuan Province, China. Sichuan Province is located in the Southwest of China and is a good place to conduct this research as lineage culture is in general still rather intact. Jintang County is located northeast of the Chengdu Plain, $28 \mathrm{~km}$ from the center of Chengdu. It is located in the third of the three circles that make Chengdu, i.e. in the outskirts of Chengdu and an area that both keeps traditional lineage culture and is influenced by factors of rapid economic development and out-migration. Jintang County is comprised of 21 townships, three of them are completely urbanized, which is why for the survey, villages were selected from the 18 townships. For each of these townships, 2 - 3 villages were selected, based on the information of experienced local government staff regarding which villages would have a lot of small 
irrigation infrastructures. We randomly selected household heads as respondents, and determined the number of households by the ratio of one ten thousandth of the population of the township, the distribution of samples across townships ranged between $3.28 \%-7.66 \%$ of the whole sample. The survey was conducted in August 2018. Jintang County is located in a monsoon-influenced humid subtropical climate, which means that farmers carry out agricultural production, and need small irrigation infrastructures accordingly, throughout the year. Survey questions with regard to whether respondents recently contributed to the provision of irrigation infrastructures hence could be validly answered, ranged between $3.28 \%$ and $7.66 \%$ of the whole sample. The survey was conducted in August 2018.

\subsubsection{Data Description}

The survey was conducted in August 2018, and the investigators were divided into three groups so as to conduct the survey simultaneously. There were 617 questionnaires that were filled in, the sample consisted of 548 valid questionnaires, and the effective response rate was $88.82 \%$. Of the respondents, $66.61 \%$ were male, and the age group that officially comprised the labor force, namely, between 21 - 60 years old, accounted for $66.97 \%$. This article uses the head of the household's education level as a proxy for the household's education level; $45.26 \%$ of the heads of households had a primary school education or below, $33.03 \%$ graduated from junior middle school. Technical secondary/high school degrees accounted for $15.15 \%$, and $6.20 \%$ of the heads of households had a college degree or an even higher educational degree. Heads of households living in the village for less than 20 years accounted for only $5.66 \%$, while $10.58 \%$ of the heads of household had been living in the village for between 20 and 39 years, $49.82 \%$ had been living in the village for 40 to 59 years, and $14.78 \%$ had been living in the village for more than 60 years. Heads of households who were party members accounted for $33.94 \%$, and $96.35 \%$ were registered as rural citizens, i.e., had a rural Hukou, while $3.65 \%$ had an urban Hukou. Of the respondents, $62.77 \%$ of the households had $0-1$ member who had out-migrated, $33.03 \%$ had 2 - 3, and $4.20 \%$ had 4 - 12 members who had out-migrated. For household labor engaged in agricultural production, $39.78 \%$ of households had $0-1$ laborer working in agriculture, $47.99 \%$ had $2-3$, and $12.23 \%$ had 4 - 12 household members working in agriculture (see Tab. $1)$.

Table 1 Descriptive Statistics

\begin{tabular}{|c|c|c|c|c|c|c|c|}
\hline Item & Category & Quantity & Percentage & Item & Category & Quantity & Percentage \\
\hline \multirow[t]{2}{*}{ Gender } & Male & 365 & 66.61 & Education level & $\begin{array}{c}\text { Primary school and } \\
\text { below }\end{array}$ & 248 & 45.26 \\
\hline & Female & 183 & 33.39 & & $\begin{array}{l}\text { Junior middle high } \\
\text { school }\end{array}$ & 181 & 33.03 \\
\hline \multirow[t]{4}{*}{ Age } & $\begin{array}{c}\text { Age of } 16- \\
20\end{array}$ & 13 & 2.37 & & $\begin{array}{c}\text { Technical secondary / } \\
\text { high school }\end{array}$ & 83 & 15.15 \\
\hline & Age $21-40$ & 68 & 12.41 & & College & 34 & 6.20 \\
\hline & Age $41-60$ & 299 & 54.56 & & Master $/ \mathrm{PhD}$ & 2 & 0.36 \\
\hline & $\begin{array}{c}\text { Over the age } \\
\text { of } 60\end{array}$ & 170 & 31.02 & Period of living in village & Under 20 years & 31 & 5.66 \\
\hline \multirow[t]{3}{*}{ Political status } & $\begin{array}{c}\text { Party } \\
\text { member }\end{array}$ & 102 & 18.61 & & $20-39$ years & 58 & 10.58 \\
\hline & $\begin{array}{l}\text { Communist } \\
\text { Youth } \\
\text { League } \\
\text { member } \\
\end{array}$ & 24 & 4.38 & & $40-59$ years & 273 & 49.82 \\
\hline & $\begin{array}{l}\text { General } \\
\text { public }\end{array}$ & 422 & 77.01 & & Over 60 years & 186 & 33.94 \\
\hline \multirow{2}{*}{ Households' Hukou } & Urban Hukou & 20 & 3.65 & \multirow{3}{*}{ Labor out-migrated (no.) } & $0-1$ & 344 & 62.77 \\
\hline & Rural Hukou & 528 & 96.35 & & $2-3$ & 181 & 33.03 \\
\hline \multirow{4}{*}{$\begin{array}{l}\text { Willingness to participate in } \\
\text { collective irrigation } \\
\text { management }\end{array}$} & $1-1.75$ & 35 & 6.39 & & $4-6$ & 23 & 4.20 \\
\hline & $2-2.75$ & 37 & 6.75 & \multirow{3}{*}{$\begin{array}{l}\text { Household labor engaged } \\
\text { in agricultural production } \\
\text { (no.) }\end{array}$} & $0-1$ & 218 & 39.78 \\
\hline & $3-3.75$ & 98 & 17.88 & & $2-3$ & 263 & 47.99 \\
\hline & $4-5$ & 388 & 70.80 & & $4-12$ & 67 & 12.23 \\
\hline \multirow{5}{*}{$\begin{array}{l}\text { Relationship with villagers } \\
\text { (see Tab. 4) }\end{array}$} & 1 & 0 & 0 & \multirow{2}{*}{$\begin{array}{l}\text { Participation in collective } \\
\text { irrigation management }\end{array}$} & Yes & 257 & 46.90 \\
\hline & 2 & 1 & 0.18 & & No & 291 & 53.10 \\
\hline & 3 & 44 & 8.03 & \multirow{6}{*}{ Total income (see Tab. 4) } & 1 & 62 & 11.31 \\
\hline & 4 & 128 & 23.36 & & 2 & 171 & 31.20 \\
\hline & 5 & 375 & 68.43 & & 3 & 142 & 25.91 \\
\hline \multirow{6}{*}{$\begin{array}{l}\text { Agricultural income (see } \\
\text { Tab. 4) }\end{array}$} & 1 & 481 & 87.77 & & 4 & 81 & 14.78 \\
\hline & 2 & 57 & 10.40 & & 5 & 39 & 7.12 \\
\hline & 3 & 6 & 1.09 & & 6 & 53 & 9.67 \\
\hline & 4 & 2 & 0.36 & & & & \\
\hline & 5 & 1 & 0.18 & & & & \\
\hline & 6 & 1 & 0.18 & & & & \\
\hline Total number & & 548 & & Total number & & 548 & \\
\hline
\end{tabular}

\subsection{Independent Variables and Dependent Variables}

Two dependent variables were used, namely, lineage members' actual participation in collective irrigation infrastructure management $\left(Y_{1}\right)$ and lineage members' willingness to participate in collective irrigation infrastructure management $\left(Y_{2}\right)$. The dependent variable, $Y_{1}$, was measured by asking the following question: "Did 
you participate in collective action of managing small irrigation infrastructure during the last 1 year (both by contributing labor or money)?". The answer categories were "yes" or "no". Responses were fairly equally spread across these two answer categories.

The dependent variable, $Y_{2}$, was measured by providing four statements concerning respondents' willingness to contribute to irrigation infrastructure management (see Tab. 2). Farmers had to respond by indicating the degree to which they agreed with the respective statement. The answer categories ranged from 1 (low willingness) to 5 (strong willingness). As an indication of a respondents' overall willingness to contribute to collective irrigation infrastructure management, the average of the values from the four statements was taken. As Section 3.1.2 shows, nearly three quarters of the respondents showed a rather high willingness to participate in irrigation infrastructure management.

Table 2 Statements regarding respondents' willingness to contribute to collective irrigation infrastructure management.

\begin{tabular}{|l|l|}
\hline & \multicolumn{2}{|c|}{ Irrigation infrastructure management. } \\
\hline 1 & $\begin{array}{l}\text { I am willing to participate in collective irrigation infrastructure } \\
\text { management. }\end{array}$ \\
\hline 2 & $\begin{array}{l}\text { I think collective irrigation infrastructure management is my own } \\
\text { business. }\end{array}$ \\
\hline 3 & $\begin{array}{l}\text { I am willing to donate my money, labor, supplies or anything else } \\
\text { to participate in collective irrigation infrastructure management. }\end{array}$ \\
\hline 4 & $\begin{array}{l}\text { I will inform and invite other village members to participate in } \\
\text { collective irrigation infrastructure management. }\end{array}$ \\
\hline
\end{tabular}

The independent variables were lineage identity $\left(X_{1}\right)$ and strength of lineage network ties $\left(X_{2}\right)$. To measure lineage identity $\left(X_{1}\right)$, the organizational identity scale was used (see Tab. 3). If the score was higher, the respondent's lineage organizational identity was higher. The internal consistency coefficient of the scale was Cronbach's Alpha $=0.929$. There was a moderate correlation among the items, and each item was significantly correlated with the total score of the questionnaire, indicating that the questionnaire has a good reliability and validity, and can accurately measure participants' lineage organizational identity.
Table 3 Lineage identity scale.

Items

1 When someone criticizes my lineage, it is like a personal insult.

2 I am very interested in what others think about my lineage.

3 When I talk about this lineage, I usually say "we" rather than

3 "they".

4 This lineage's successes are my successes.

5 When someone praises this lineage, it feels like a personal

5 compliment

6 If a report in the media criticized the lineage, I would feel embarrassed.

The strength of the lineage network ties $\left(X_{2}\right)$ was measured with two indicators. First, whether or not the lineage had an ancestral temple [20], and second, whether it had a genealogy [21]. Ancestral temples are the place for lineages to worship and sacrifice, and genealogies are the records of descent of a clan, which have been widely used to indicate the strength of lineage network ties [20]. Respondents were accordingly asked, "Is there any ancestral temple or genealogy of your household". The answer categories were as follows, "neither with an ancestral temple nor a genealogy", "with an ancestral temple", "with a genealogy", or "both". In the data analysis, "0" means "none", "1" means with an ancestral temple or with a genealogy, and "2" means both.

\subsection{Control Variables}

In order to observe the effect of independent variables $X_{1}$ and $X_{2}$, this article controls for some other variables which may also have an effect on $Y_{1}$ and $Y_{2}$. These variables were first about the household head, i.e. the education level of the household head $\left(X_{3}\right)$. Further control variables were the period of living in the village $\left(X_{4}\right)$; the kind of Hukou $\left(X_{5}\right)$; the number of household members who have outmigrated for work $\left(X_{6}\right)$; the number of household labor engaged in agricultural production $\left(X_{7}\right)$; agriculture land area $\left(X_{8}\right)$; relationship with villagers $\left(X_{9}\right)$; agricultural income $\left(X_{10}\right)$; total income $\left(X_{11}\right)$. The definitions of all the variables are provided in Tab. 4.

Table 4 Variable definitions and description.

\begin{tabular}{|l|l|l|l|}
\hline \multicolumn{1}{|c|}{ Variables definitions } & \multicolumn{1}{|c|}{ Index } & \multicolumn{1}{|c|}{ Variables definitions } \\
\hline $\begin{array}{l}\text { Participation in collective irrigation } \\
\text { infrastructure management in the past } \\
\text { year }\left(Y_{1}\right)\end{array}$ & Yes $=1$, no $=0$ & Hukou $\left(x_{5}\right)$ & Hukou of urban $=1$, Hukou of rural $=0$ \\
\hline $\begin{array}{l}\text { Willingness to participate in collective } \\
\text { irrigation infrastructure management }\left(Y_{2}\right)\end{array}$ & $\begin{array}{l}\text { Average continuous variable } \\
\text { value on a five-point scale }\end{array}$ & $\begin{array}{l}\text { Household labor out- } \\
\text { migrated }\left(x_{6}\right)\end{array}$ & $\begin{array}{l}\text { Reported value of the respondent }(\text { number } \\
\text { of people })\end{array}$ \\
\hline Lineage identity $\left(X_{1}\right)$ & See Tab. 3 & $\begin{array}{l}\text { Household labor engaged in } \\
\text { agricultural production }\left(x_{7}\right)\end{array}$ & $\begin{array}{l}\text { Reported value of the respondent (number } \\
\text { of people) }\end{array}$ \\
\hline Strength of lineage network $\left(X_{2}\right)$ & $\begin{array}{l}\text { None }=0 ; \text { with ancestral temple } \\
\text { or genealogy }=1 ; \text { both }=2\end{array}$ & Agricultural land area $\left(x_{8}\right)$ & Reported value of the respondent (mu). \\
\hline Education level of the household head $\left(x_{3}\right)$ & $\begin{array}{l}2 ; \text { technical secondary/high } \\
\text { school }=3 ; \text { college }=4 ; \\
\text { Masters/PhD }=5\end{array}$ & $\begin{array}{l}\text { Relationship with villagers } \\
\left(x_{9}\right)\end{array}$ & $\begin{array}{l}\text { Good, very harmonious }=5 ; \text { nood }=4 ; \\
\text { good }=2, \text { very poor, large frictions, } \\
\text { hostility }=1\end{array}$ \\
\hline Period of living in the village $\left(x_{4}\right)$ & $\begin{array}{l}\text { Reported value of the respondent } \\
\text { (years })\end{array}$ & $\begin{array}{l}\text { Reported value of the respondent }(\mathrm{RMB}): \\
1=1 \text { less than } 10,000 ; 2=10,000-30,000 ; \\
3=30,000-50,000 ; 4=50,000-70,000 ; \\
5=70,000-100,000 ; 6 \geq 100,000\end{array}$ \\
\hline
\end{tabular}

\section{RESULTS}

This article established six regression models (see Tab. 5). In Model 1 to Model 3, the dependent variable was lineage members' participation in collective irrigation infrastructure management $\left(Y_{1}\right)$. In Model 4 to Model 6, the dependent variable was the willingness to participate in collective irrigation infrastructure management $\left(Y_{2}\right)$. 
Logistic and Tobit regressions were carried out using Stata 14.0. $Y_{1}$ was defined as a categorical variable (with values of 0 and 1), so Model 1 to Model 3 are the logistic regression models. $Y_{2}$ was defined as a continuous variable, because the average of the values from the four underlying statements (see Tab. 2) was used as an indication of respondents' willingness. Model 4 to Model 6 were accordingly analyzed using Tobit regression.

Table 5 Regression analysis results.

\begin{tabular}{|c|c|c|c|c|c|c|}
\hline \multirow[b]{2}{*}{ Independent variables } & \multicolumn{6}{|c|}{ Dependent variables } \\
\hline & $\begin{array}{c}\text { Logistic } \\
\text { model } 1\left(Y_{1}\right)\end{array}$ & $\begin{array}{c}\text { Logistic } \\
\text { model } 2\left(Y_{1}\right)\end{array}$ & $\begin{array}{c}\text { Logistic } \\
\text { model } 3\left(Y_{1}\right)\end{array}$ & $\begin{array}{c}\text { Tobit } \\
\text { Model } 4\left(Y_{2}\right)\end{array}$ & $\begin{array}{c}\text { Tobit } \\
\text { model } 5\left(Y_{2}\right)\end{array}$ & $\begin{array}{c}\text { Tobit } \\
\text { model } 6\left(Y_{2}\right)\end{array}$ \\
\hline $\begin{array}{l}\text { Lineage organizational } \\
\text { identity }\left(X_{1}\right)\end{array}$ & & $\begin{array}{c}0.3916 * * * \\
(0.08020)\end{array}$ & $\begin{array}{c}0.3449 * * * \\
(0.08180)\end{array}$ & $\begin{array}{l}0.1576^{* *} \\
(0.05351)\end{array}$ & & $\begin{array}{l}0.1437 * * \\
(0.05404)\end{array}$ \\
\hline $\begin{array}{l}\text { Strength of lineage network } \\
\text { ties }\left(X_{2}\right)\end{array}$ & $\begin{array}{l}0.6722 * * * \\
(0.13692)\end{array}$ & & $\begin{array}{l}0.5966^{* * *} \\
(0.14020)\end{array}$ & & $\begin{array}{c}0.1821^{*} \\
(0.09055)\end{array}$ & $\begin{array}{c}0.1426 \\
(0.09128)\end{array}$ \\
\hline $\begin{array}{l}\text { Education level of head of } \\
\text { household }\left(X_{3}\right)\end{array}$ & $\begin{array}{c}0.2707^{*} \\
(0.11097) \\
\end{array}$ & $\begin{array}{c}0.1921 \\
(0.11316)\end{array}$ & $\begin{array}{c}0.1530 \\
(0.11608) \\
\end{array}$ & $\begin{array}{c}0.0337 \\
(0.07715) \\
\end{array}$ & $\begin{array}{c}0.0711 \\
(0.07559) \\
\end{array}$ & $\begin{array}{c}0.0251 \\
(0.07706) \\
\end{array}$ \\
\hline Period of living in village $\left(X_{4}\right)$ & $\begin{array}{c}-0.002 \\
(0.00665)\end{array}$ & $\begin{array}{l}-0.0005 \\
(0.00646)\end{array}$ & $\begin{array}{l}-0.0010 \\
(0.00661)\end{array}$ & $\begin{array}{l}-0.0064 \\
(0.00435)\end{array}$ & $\begin{array}{c}-0.0067 \\
(0.00436)\end{array}$ & $\begin{array}{c}-0.0064 \\
(0.00434)\end{array}$ \\
\hline Hukou $\left(X_{5}\right)$ & $\begin{array}{c}0.1308 \\
(0.49798)\end{array}$ & $\begin{array}{c}0.0769 \\
(0.49438) \\
\end{array}$ & $\begin{array}{c}0.0689 \\
(0.50654)\end{array}$ & $\begin{array}{c}-0.5481 \\
(0.33089)\end{array}$ & $\begin{array}{c}-0.5262 \\
(0.33100)\end{array}$ & $\begin{array}{l}-0.5553 \\
(0.32998)\end{array}$ \\
\hline $\begin{array}{l}\text { Number of household } \\
\text { workers out-migrated }\left(X_{6}\right)\end{array}$ & $\begin{array}{l}-0.0751 \\
(0.09269)\end{array}$ & $\begin{array}{l}-0.0036 \\
(0.9164)\end{array}$ & $\begin{array}{l}-0.0518 \\
(0.09428)\end{array}$ & $\begin{array}{l}-0.0360 \\
(0.06108)\end{array}$ & $\begin{array}{l}-0.0583 \\
(0.06135)\end{array}$ & $\begin{array}{c}-0.0459 \\
(0.06119)\end{array}$ \\
\hline $\begin{array}{l}\text { Number of household } \\
\text { workers engaged in } \\
\text { agricultural production }\left(X_{7}\right)\end{array}$ & $\begin{array}{c}-0.6873 \\
(0.07097)\end{array}$ & $\begin{array}{l}-0.0319 \\
(0.07033)\end{array}$ & $\begin{array}{l}-0.0419 \\
(0.07248)\end{array}$ & $\begin{array}{c}0.0359 \\
(0.04672)\end{array}$ & $\begin{array}{c}0.0217 \\
(0.04651)\end{array}$ & $\begin{array}{c}0.0349 \\
(0.04657)\end{array}$ \\
\hline Agricultural land area $\left(X_{8}\right)$ & $\begin{array}{c}0.0026 \\
(0.00496)\end{array}$ & $\begin{array}{c}0.0024 \\
(0.00534)\end{array}$ & $\begin{array}{c}0.0018 \\
(0.00493)\end{array}$ & $\begin{array}{l}0.1236 * * * \\
(0.02730)\end{array}$ & $\begin{array}{l}0.1255^{* * *} \\
(0.02742)\end{array}$ & $\begin{array}{l}0.1193 * * * \\
(0.02732)\end{array}$ \\
\hline $\begin{array}{l}\text { Relationship with villagers } \\
\left(X_{9}\right)\end{array}$ & $\begin{array}{c}-0.0594 \\
(0.15110)\end{array}$ & $\begin{array}{l}-0.0146 \\
(0.15033)\end{array}$ & $\begin{array}{c}-0.0527 \\
(0.15379)\end{array}$ & $\begin{array}{c}0.1156 \\
(0.10201)\end{array}$ & $\begin{array}{c}0.0979 \\
(0.10069)\end{array}$ & $\begin{array}{c}0.1063 \\
(0.10007)\end{array}$ \\
\hline Agricultural income $\left(X_{10}\right)$ & $\begin{array}{l}0.7254 * * \\
(0.25063)\end{array}$ & $\begin{array}{l}0.6689 * * \\
(0.24607)\end{array}$ & $\begin{array}{l}0.6919 * * \\
(0.24702)\end{array}$ & $\begin{array}{c}0.2904 \\
(0.15225)\end{array}$ & $\begin{array}{c}0.3015^{*} \\
(0.15264)\end{array}$ & $\begin{array}{c}0.2959^{*} \\
(0.15166)\end{array}$ \\
\hline Total income $\left(X_{11}\right)$ & $\begin{array}{c}0.0139 \\
(0.07456) \\
\end{array}$ & $\begin{array}{l}-0.1085 \\
(0.07468)\end{array}$ & $\begin{array}{c}-0.0495 \\
(0.07762)\end{array}$ & $\begin{array}{c}0.0368 \\
(0.05013)\end{array}$ & $\begin{array}{c}0.0783 \\
(0.04981)\end{array}$ & $\begin{array}{c}0.0498 \\
(0.05065)\end{array}$ \\
\hline Constant term & $\begin{array}{l}-1.3333 \\
(0.86365)\end{array}$ & $\begin{array}{l}-1.9561^{*} \\
(0.87267)\end{array}$ & $\begin{array}{l}-2.0387 * \\
(0.89756)\end{array}$ & $\begin{array}{l}2.5642 * * * \\
(0.58249)\end{array}$ & $\begin{array}{c}2.8653 * * * \\
(0.57273)\end{array}$ & $\begin{array}{l}2.5608 * * * \\
(0.58069)\end{array}$ \\
\hline Sample size & 548 & 548 & 548 & 548 & 548 & 548 \\
\hline
\end{tabular}

Note: Standard errors are in parentheses; $p$ - values are shown with stars, ${ }^{*} p<0.05,{ }^{* *} p<0.01,{ }^{* * *} p<0.001$

As can be seen from Tab. 5, for the case of the collective management of an irrigation infrastructure, lineage becomes important in its characteristic as a social network as well as for a hierarchically organized clan. For respondents' willingness to contribute to collective irrigation management, identification with the clan is more likely to motivate reported willingness than network strength (see Model 4 and Model 5, respectively). In addition, Model 6 shows that when this article put $X_{1}$ and $X_{2}$ together to regress only lineage organizational identity, $X_{1}$ has a significant impact on $Y_{2}$. The growth in respondents' willingness contributes to irrigation infrastructure management, which is moderate. For de facto participation, the influence of lineage is even stronger, independent of whether it takes effect as a network (Model 1) or organization (Model 2).

Another variable that is significant for both dependent variables is agricultural income. The more economically dependent a household is on agriculture, the more likely it contributes to infrastructure management, and the more likely it expresses its willingness to contribute. While contribution to irrigation infrastructure management is not correlated with the size of agricultural land, household heads who have more land are very likely to express a higher willingness to contribute. This correlation may be understood as a socially desirable answer, given the fact that for de facto contribution, no correlation can be found at all.

\section{CONCLUSIONS}

In the context of weakening formal institutions in the countryside, this paper looked at the role of lineage informal institutions in facilitating collective irrigation infrastructure management. Lineage can facilitate public goods provision through collective action, or by making lineage members accountable. This article builds on this literature by asking what exactly within lineage triggers farmers' willingness to participate in collective action, whether lineage is used as a social network or an organization.

The analysis incorporated a variety of factors that were presumed to have an influence on farmers' contribution or stated willingness to contribute to collective irrigation infrastructure management. In addition, even if factors like agricultural income or agricultural land area positively influence respondents' contribution, lineage has the most significant influence.

Based on data from empirical research in Sichuan Province, and using logistic models and tobit models, this article hence found that both lineage as an organization and lineage as a social network influence farmers' contribution to collective irrigation infrastructure management. Identification with the clan, however, is more important for farmers' expressed willingness, which contributes to irrigation infrastructure management. This finding is supported by the literature on social and organizational identity, separately, which show identification with an organization (or group) as enabling a commitment to an organization and its activities.

Based on these findings, this article concludes that the current conceptual divide into lineage as a network and an organization or a patriarchal clan system may need to be reconsidered. This article shows that research might be 
able to capture lineage more realistically if both understandings are employed. In the case at hand, the strength of the ties within the community of clan members, as well as the "chain of command", have their influence on lineage members' contribution to irrigation infrastructure management. However, for other areas of issue, either lineage's network structure or its hierarchical organization may be more important, and to better understand the working of lineage, more research is needed on the conditions under which both of them take effect. The example of lineage as a mediator of jobs may, however, also show some of the limits of lineage for the provision of public goods. Public goods are fundamental for a society. While the results show that lineage can motivate lineage members to take over tasks in irrigation infrastructure management, the question arises as to how far reliance on lineage can also lead to the exclusion of non-clan members from the provision of public goods. This method is suitable for measuring the influence of organization identity. Only some aspects regarding the strength of social networks on collective action have been considered for informal institutions. More research needs to be done on the conditions under which the involvement of lineage in the provision of public goods can lead to a just distribution of access.

\section{REFERENCES}

[1] Yin, L. C. (2003). Do traditional values still exist in modern Chinese societies? Asia Europe Journal, 1, 43-59. https://doi.org/10.1007/s103080200001

[2] Hu, B. (2007). Informal institutions and rural development in China. Routledge. https://doi.org/10.4324/9780203947449

[3] Tsai, L. L. (2007). Solidary groups, informal accountability, and local public goods provision in rural China. American Political Science Review, 101, 355-372. https://doi.org/10.1017/S0003055407070153

[4] Xu, Y. \& Yao, Y. (2015) Informal institutions, collective action, and public investment in rural china. American Political Science Review, 109, 371-391. https://doi.org/10.1017/S0003055415000155

[5] Peng, Y. (2005). Lineage networks, rural entrepreneurs, and Max Weber. Emerald Group Publishing Limited, 327-355. https://doi.org/10.1016/S0277-2833(05)15013-4

[6] Peng, Y. (2010). When formal laws and informal norms collide: Lineage networks versus birth control policy in China. American Journal of sociology, 116, 770-805. https://doi.org/10.1086/657102

[7] Pan, Y. (2011). Born with the Right Surname? Lineage Networks and Political and Economic Opportunities in Rural China. Louisiana State University, Working Paper.

[8] Lee, E., Park, T., \& Koo, B. (2015). Identifying organizational identification as a basis for attitudes and behaviors: A meta-analytic review. Psychological bulletin, 141, 1049. https://doi.org/10.1037/bul0000012

[9] Wang, X. \& Yan, S. (2014). The effect of China's agricultural tax abolition on rural families' incomes and production. China Economic Review, 29, 185-199. https://doi.org/10.1016/j.chieco.2014.04.010

[10] Anderies, J. M., Janssen, M. A., Lee, A., et al. (2013). Environmental variability and collective action: Experimental insights from an irrigation game: the journal of the International Society for Ecological Economics. Ecological Economics, 93, 166-176. https://doi.org/10.1016/j.ecolecon.2013.04.010

[11] Fei, X. (1992). From the Soil: The Foundations of Chinese Society: University of California Press. https://doi.org/10.1525/9780520912489

[12] Fei, H. (1946). Peasantry and gentry: An interpretation of Chinese social structure and its changes. American Journal of sociology, 52, 1-17. https://doi.org/10.1086/219914

[13] Kelly, C. (2011) Group Identification, Intergroup Perceptions and Collective Action. European Review of Social Psychology, 4, 59-83. https://doi.org/10.1080/14792779343000022

[14] Turner, J. C. (1982). Towards a cognitive redefinition of the social group. Cahiers De Psychologie Cognitive, 1, 93-118.

[15] Gardner, W. L. \& Garr-Schultz, A. (2017). Understanding our groups, understanding ourselves: the importance of collective identity clarity and collective coherence to the self. Self-Concept Clarity. 4,125-143. https://doi.org/10.1007/978-3-319-71547-6_7

[16] Haslam, S. A. \& Ellemers, N. (2005). Social identity in industrial and organizational psychology: Concepts, controversies and contributions. International review of industrial and organizational psychology, 20, 39-118. https://doi.org/10.1002/0470029307.ch2

[17] Hatch, M. J. \& Schultz, M. (1997). Relations between organizational culture, identity and image. European Journal of Marketing, 31, 356-365. https://doi.org/10.1108/03090569710167583

[18] Greene, S. (2004). Social Identity Theory and Party Identification. Social science quarterly, 85, 136-153. https://doi.org/10.1111/j.0038-4941.2004.08501010.x

[19] Yu, Y. \& Fang, W. (2020). Households' Willingness to Contribute to Irrigation Infrastructure in Rural China: The Role of Lineage and Outmigration. Water, 12, 1852. https://doi.org/10.3390/w12071852

[20] Zhang, T. \& Zhao, X. (2014) Do Kinship Networks Strengthen Private Property? Evidence from Rural China. Journal of Empirical Legal Studies, 11, 505-540. https://doi.org/10.1111/jels.12048

[21] Tsai, L. L. (2007). Solidary groups, informal accountability, and local public goods provision in rural China. American Political Science Review, 101, 355-372. https://doi.org/10.1017/S0003055407070153

\section{Contact information}

\section{Yu YANG}

1) College of Economics and Management, Huzhou University, No.

759, East 2nd Road, Huzhou, 313000 China

2) Copernicus Institute of Sustainable Development, Utrecht University, Utrecht, Netherlands

E-mail: yangyu_hzu@163.com 